\title{
Mineral- und \\ Erzlagerstättenkunde
}

\author{
Von
}

\author{
H. Huttenlocher
}

Professor an der Universität Bern

I

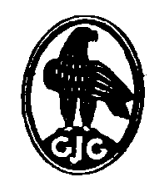

WALTER D E GR UYTE R \& C O. vormale G. J. Gōachen'acbo Verlagshandlung - J. Guttentag, Verlagsbuchbendlung - Georg Roimer - Karl J. Trübner - Veit \& Comp. Berlin 1954 
Alle Rechte, einschl, der Rechte der Herstellung von Photokopien und Mikrofilmen, von der Verlagshandlung vorbehalten.

\author{
Copyright 1954 by \\ WALTER DE GRUYTER \& CO. \\ Berlin W 35, Genthiner Str. 13.
}

Archiv-Nr, 111014

Satz u. Druck: Budikunst, Berlin W 35

Printed in Germany. 